\title{
Simultaneous changes in the function and expression of beta 1 integrins during the growth arrest of poorly differentiated colorectal cells (LISP-1)
}

\section{R.A. Roela, M.M. Brentani, M.L.H. Katayama, M. Reis and M.H.H. Federico}

\author{
Disciplina de Oncologia, Departamento de Radiologia, \\ Faculdade de Medicina, Universidade de São Paulo, \\ São Paulo, SP, Brasil
}

\begin{abstract}
Correspondence

M.H.H. Federico

Disciplina de Oncologia

Departamento de Radiologia

Faculdade de Medicina, USP

Av. Dr. Arnaldo, 455, Sala 4112

01246-903 São Paulo, SP

Brasil

Fax: +55-11-3082-6580

E-mail: federico@usp.br

Presented at SIMEC 2002 (International Symposium

on Extracellular Matrix),

Angra dos Reis, RJ, Brazil,

October 7-10, 2002.

Research supported by PRONEX (No. 4196086900/7038-6). Part of a Master's thesis presented by R.A. Roela to the Instituto Butantan, USP, São Paulo, SP, Brazil.

Publication supported by FAPESP ..........

Received December 13, 2002 Accepted July 1, 2003

Cells usually lose adhesion and increase proliferation and migration during malignant transformation. Here, we studied how proliferation can affect the other two characteristics, which ultimately lead to invasion and metastasis. We determined the expression of $\beta 1$ integrins, as well as adhesion and migration towards laminin-1, fibronectin, collagens type I and type IV presented by LISP-1 colorectal cancer cells exposed to $2.5 \%$ dimethyl sulfoxide (DMSO), an agent capable of decreasing proliferation in this poorly differentiated colorectal cell line. Untreated cells (control), as shown by flow cytometry and monoclonal antibodies, expressed $\alpha 2(63.8 \pm 11.3 \%$ positive cells $)$, $\alpha 3(93.3 \pm 7.0 \%), \alpha 5(50.4 \pm 12.0 \%)$ and $\alpha 6(34.1 \pm 4.9 \%)$ integrins but not $\alpha 1, \alpha 4, \alpha \mathrm{v}$ or $\beta 4$. Cells adhered well to laminin-1 $(73.4 \pm 6.0 \%)$ and fibronectin $(40.0 \pm 2.0 \%)$ substrates but very little to collagens. By using blocking monoclonal antibodies, we showed that $\alpha 2, \alpha 3$ and $\alpha 6$ mediated laminin-1 adhesion, but neither $\alpha 3$ nor $\alpha 5$ contributed to fibronectin adherence. DMSO arrested cells at G0/G1 (control: $55.0 \pm$ 2.4\% vs DMSO: $70.7 \pm 2.5 \%)$ while simultaneously reducing $\alpha 5(24.2$ $\pm 19 \%)$ and $\alpha 6(14.3 \pm 10.8 \%)$ expression as well as c-myc mRNA (7fold), the latter shown by Northern blotting. Although the adhesion rate did not change after exposure to DMSO, $\alpha 3$ and $\alpha 5$ played a major role in laminin-1 and fibronectin adhesion, respectively. Migration towards laminin-1, which was clearly increased upon exposure to DMSO (control: $6 \pm 2$ cells $v s$ DMSO: $64 \pm 6$ cells), was blocked by an antibody against $\alpha 6$. We conclude that the effects of DMSO on LISP-1 proliferation were accompanied by concurrent changes in the expression and function of integrins, consequently modulating adhesion/ migration, and revealing a complex interplay between function/expression and the proliferative state of cells.
\end{abstract}

\section{Introduction}

Normal intestinal epithelial cells exist adherent to a basement membrane composed of laminin-1 and collagen type IV, whereas the interstitial matrix presents collagen type I
Key words

- Cell adhesion molecules

- Cell migration

- Integrin

- Cell cycle

- DMSO and fibronectin. Cell interaction with these components involves a class of transmembrane heterodimeric cell adhesion receptors, the integrins, such as $(\alpha 2-\alpha 6) \beta 1, \alpha v \beta 1$ and $\alpha 6 \beta 4$ found in normal colonic mucosa $(1,2)$.

The presence or absence of individual 
integrins has often been implicated in changes in adhesive properties, neoplastic transformation and invasive processes in colon adenocarcinoma (2-5). Some reports have associated integrins with cycle status in other cell models (6-8).

Although it is generally assumed that changes in integrins underlie $(1,9)$ changes in cell adhesion and migration (10), and that these changes occur during human colorectal differentiation and carcinogenesis (2), we know very little about the relationship between cell cycle and integrin expression or function (11). We do not know whether or not decreased proliferation can, per se, affect integrin quantitatively and, if this is true, if changes in integrins displayed by a given cell population are responsible for changes in migration or adhesive properties.

To answer this question, we first investigated which agents known to exert an antiproliferative effect upon colonic cell lines affected the expression and binding affinity of $\beta 1$ integrins expressed by LISP- 1 cells, a poorly differentiated colorectal cancer cell line derived from a hepatic metastasis. Four different antiproliferative agents described to block proliferation in colorectal cell lines were tested: glucose (12), all-trans retinoic acid (13), 1,25-dihydroxyvitamin $\mathrm{D}_{3}(14)$ and dimethyl sulfoxide (DMSO) $(15,16)$.

\section{Material and Methods}

\section{Cell and culture conditions}

LISP-1 cells (17) were donated by the Ludwig Institute (São Paulo Branch, São Paulo, SP, Brazil). Cells were grown in Dulbecco's modified Eagle's medium (DMEM, Sigma, St. Louis, MO, USA) supplemented with $10 \%$ fetal bovine serum (FBS, Gibco-BRL, Rockville, MD, USA), $10 \mathrm{mM}$ HEPES (Gibco-BRL), and $40 \mu \mathrm{g} / \mathrm{ml}$ gentamicin, at $37^{\circ} \mathrm{C}$, in an atmosphere of $5 \%$ $\mathrm{CO}_{2}, 95 \%$ air. Cells were grown in monolayer cultures, seeded at $6 \times 10^{3}$ cells $/ \mathrm{cm}^{2}$ and maintained in the absence or presence of 1.25 or $2.5 \%(\mathrm{v} / \mathrm{v})$ DMSO (Sigma), 50 or $100 \mathrm{mM}$ glucose (Sigma), $500 \mathrm{nM}$ all-trans retinoic acid (Sigma), or $10 \mathrm{nM}$ 1,25-dihydroxyvitamin $\mathrm{D}_{3}$ (Roche, Mannheim, Germany) for 10 days. The DMSO concentration chosen was the one capable of affecting proliferation but not viability, as determined by the standard Trypan exclusion method.

\section{Antibodies}

The following anti-integrin monoclonal antibodies (mAbs) were used for flow cytometric studies and antibody inhibition of adhesion and migration experiments: anti$\alpha 1$ (clone HP2B6) from Coulter-Immunotech (Miami, FL, USA); anti-B1 (clone P4C10), anti- $\alpha 2$ (clone P1E6), anti- $\alpha 3$ (clone P1B5), anti- $\alpha 4$ (clone P4G9), anti- $\alpha 5$ (clone P1D6), anti- $\alpha 6$ (clone GoH3), anti-ß4 (3E1), and anti- $\alpha v \beta 3 / \beta 5$, all from Gibco-BRL; fluorescein isothiocyanate (FITC)-conjugated sheep anti-mouse IgG, FITC-conjugated goat anti-rat IgG, and FITC-conjugated goat antirabbit (Sigma).

\section{Determination of DNA content with propidium iodide and flow cytometry}

Exponentially growing LISP-1 cells were detached from tissue culture plastic dishes, washed with PBS, kept in sodium citrate buffer at $-70^{\circ} \mathrm{C}$ and processed as described elsewhere (18). Briefly, cells were incubated with a $30 \mathrm{mg} / \mathrm{ml}$ trypsin solution for $10 \mathrm{~min}$ at room temperature, and $5 \mathrm{~g} / \mathrm{l}$ trypsin inhibitor (Sigma) and $0.1 \mathrm{~g} / 1$ ribonuclease $\mathrm{A}$ (Sigma) were then added for another $10 \mathrm{~min}$ at room temperature. Finally, $416 \mu \mathrm{g} / \mathrm{ml}$ propidium iodide (Sigma) was added $15 \mathrm{~min}$ before flow cytometric analysis. At least 10,000 events were acquired using CellQuest software (Beckton Dickinson, San Jose, CA, USA), and DNA content was measured in FL2 using a FACSCalibur flow cytometer (Beckton Dickinson) equipped with an air- 
cooled 15-mW, 488-nm argon ion laser. We determined the percent of cells in G0/G1, S and $\mathrm{G} 2 / \mathrm{M}$ phases of the cell cycle with the aid of ModFit software (Beckton Dickinson).

RNA extraction and Northern blot hybridization

Total RNA from LISP-1 cells after 10 days of DMSO treatment or in standard culture was isolated with TRIzol reagent (GibcoBRL) according to manufacturer instructions. RNA $(10 \mu \mathrm{g})$ was electrophoresed on $1 \%$ agarose-formaldehyde gels, transferred to Hybond membranes (Amersham-Pharmacia, Little Chalfont, Buckinghamshire, England) and hybridized to the following [ $\left.{ }^{32} \mathrm{P}\right]$-dCTP $(3,000 \mathrm{Ci} / \mathrm{mmol}$, Amersham-Pharmacia) random-primed (Gibco-BRL) probes: the 1.7$\mathrm{kb}$ fragment of c-myc was a gift from Dr. T.H. Habbitts, Laboratory of Molecular Biology, Cambridge, England (19), and glyceraldehyde-3-phosphate dehydrogenase was provided by Dr. P. Fort, Centre de Recherche en Biochimie des Macromolécules, Montpellier, France (20). Hybridizations were performed for $18-24 \mathrm{~h}$ at $42^{\circ} \mathrm{C}$.

\section{Integrin expression}

Cells were detached from tissue culture plastic dishes using PBS/EDTA and trypsin, incubated with DMEM supplemented with $10 \% \mathrm{FBS}$ for $2 \mathrm{~h}$ at $37^{\circ} \mathrm{C}$, washed in PBS and incubated with specific $\mathrm{mAbs}$ at predetermined concentrations for $30 \mathrm{~min}$ at $4^{\circ} \mathrm{C}$. Cells were then washed in PBS, $1 \%$ bovine serum albumin (BSA, Sigma) and incubated with secondary FITC-labeled antibodies for another $30 \mathrm{~min}$. At least 10,000 events were acquired by flow cytometry and analyzed using CellQuest software. In each experiment, fluorescence was measured in FL1, and positive cells for each integrin subunit were determined by the percent of positive cells and by mean fluorescence intensity, which was calculated by subtracting from the mean fluorescence values corresponding to cells incubated with primary and secondary antibody the corresponding values of cells incubated only with the secondary antibody.

\section{DNA and integrin dual parameter determination}

LISP-1 cells were prepared as described for the determination of integrin expression, and then fixed with 50\% cold absolute ethanol for 15 min on ice and washed twice with PBS. After $15 \mathrm{~min}$ at $37^{\circ} \mathrm{C}$ with 500 units $/ \mathrm{ml}$ ribonuclease A, $50 \mu \mathrm{g} / \mathrm{ml}$ isotonic propidium iodide was added for an additional 15 min in the dark at room temperature (21). Then, 40,000 events were acquired by FACSCalibur flow cytometry to obtain at least 10,000 events in G0/G1 (nonproliferative phase) or $\mathrm{S}+\mathrm{G} 2 / \mathrm{M}$ (proliferative phase) to analyze integrin subunit cell expression.

\section{Cell adhesion and migration assay}

The components of the extracellular matrix (ECM) used were fibronectin and collagen type IV (Sigma) and laminin-1 and collagen type I extracted from mouse Engelbreth Holm Swarm tumor (22) and rat tail (23), respectively. Cells were first labeled with $10 \mu \mathrm{Ci}\left[{ }^{35} \mathrm{~S}\right]$-methionine (specific activity $>1,000 \mathrm{Ci} / \mathrm{mmol}$ ) and washed with DMEM/0.1\% BSA. After preincubation with specific anti-integrin $\mathrm{mAbs}, 10^{4}$ cells were added for $1 \mathrm{~h}$ at $37^{\circ} \mathrm{C}$ in a $5 \% \mathrm{CO}_{2}$ atmosphere to 24-well plates precoated with 20 $\mu \mathrm{g} /$ well of laminin-1 or $10 \mu \mathrm{g} /$ well of other ECM (predetermined concentration; data not shown) overnight, at room temperature. Nonspecific binding sites were blocked with $3 \%$ BSA $\left(1 \mathrm{~h}, 37^{\circ} \mathrm{C}\right)$. Nonadherent cells were removed, ECM-attached cells were dissolved with $0.5 \mathrm{~N} \mathrm{NaOH} / 1 \% \mathrm{SDS}$, and radioactivity was counted with a Beckman $\beta$ counter (High Wycombe, Buckinghamshire, England). Each experiment was performed in triplicate 
and the percent of adherent cells was determined as follows: cell adhesion $(\%)=100 \mathrm{x}$ [(adherent cells cpm - adherent cells to BSA cpm)/total cells cpm].

The migratory properties of LISP- 1 cells were determined with the aid of a 48-well microchemotaxis chamber assay (Neuro Probe, Laguna Niguel, CA, USA) by counting the mean number of cells migrating directionally through an 8 - $\mu \mathrm{m}$ pore polyvinyl polycarbonate filter, quenched with $0.5 \%$ BSA for $1 \mathrm{~h}$ at $37^{\circ} \mathrm{C}$ and then precoated with $20 \mu \mathrm{g} /$ well laminin-1 or $10 \mu \mathrm{g} /$ well fibronectin, collagen type I or IV, for $2 \mathrm{~h}$ at $37^{\circ} \mathrm{C}$. Briefly, $5 \times 10^{3}$ cells resuspended in serumfree medium containing $0.1 \%$ BSA were added to each well, with or without antibodies against $\beta 1$ integrin receptors. The chamber was incubated for $8 \mathrm{~h}$ at $37^{\circ} \mathrm{C}$ in a humidified incubator in a $5 \% \mathrm{CO}_{2}$ atmos-

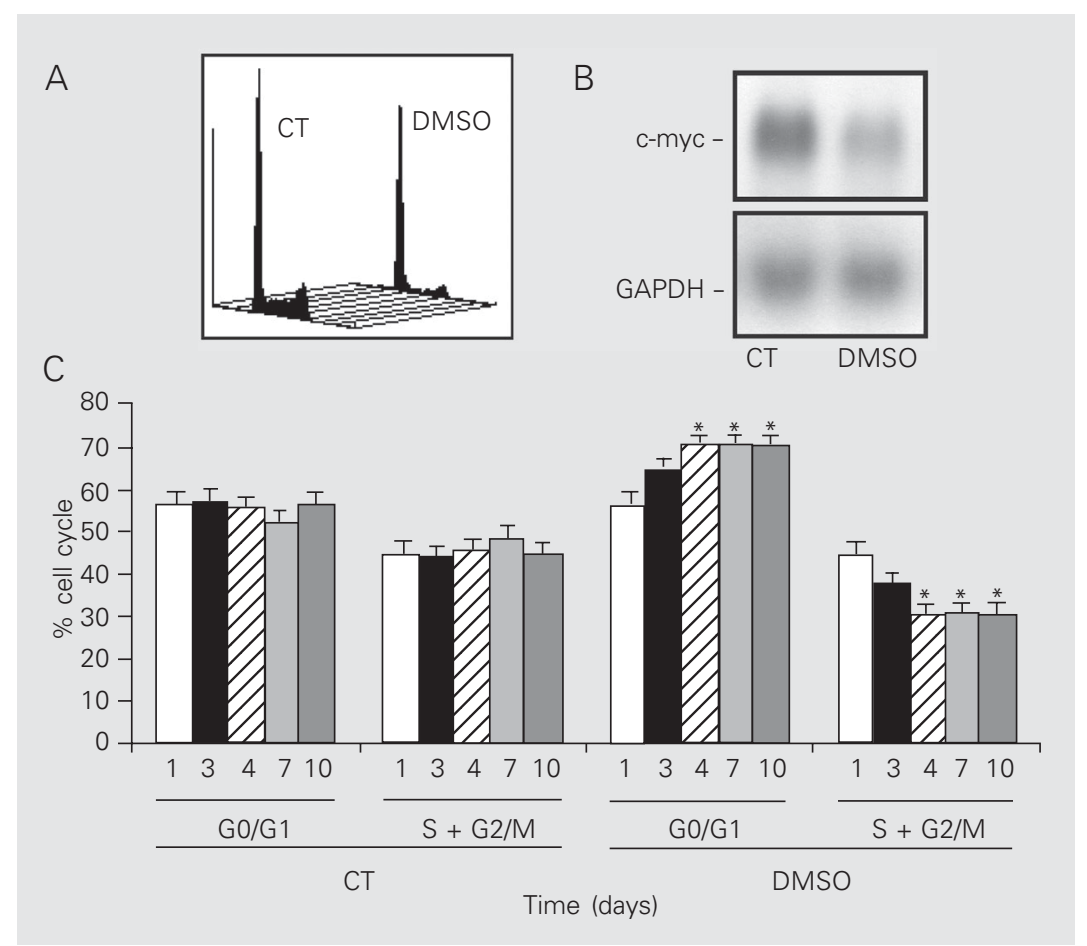

Figure 1. Dimethyl sulfoxide (DMSO, 2.5\%, v/v) inhibits LISP-1 proliferation. A, DNA quantification in control cells (CT) and in cells exposed to DMSO for 10 days. B, c-myc mRNA and GAPDH bands were obtained by Northern blot. $C, G 0 / G 1$ and $S+G 2 / M$, as percent of cells (y-axis), were obtained on different days of DMSO exposure (x-axis). Data are the mean \pm SD obtained for 7 independent experiments. GAPDH = glyceraldehyde-3phosphate dehydrogenase. ${ }^{*} \mathrm{P}<0.05$ compared to control (ANOVA). phere, and the filters were then removed, fixed, stained with $1 \%$ toluidine blue in $1 \%$ sodium tetraborate and mounted on glass slides. Nonmigrating cells were removed by wiping with a cotton swab, and finally 5 random fields of vision/well (100X objective) were counted for the evaluation of cell migratory properties. All experiments were done in quadruplicate.

\section{Statistical analysis}

Results are reported as means \pm SD. Data were analyzed statistically by ANOVA, with the level of significance set at $\mathrm{P}<0.05$.

\section{Results}

\section{Kinetic parameters of LISP-1 after DMSO treatment}

We initially set out to define which agents, among several known to provoke differentiation in colonic cells in vitro, reduced the proliferation of LISP-1 cells. Glucose (50 and $100 \mathrm{mM}$ ), $500 \mathrm{nM}$ all-trans retinoic acid and $10 \mathrm{nM}$ 1,25-dihydroxyvitamin $\mathrm{D}_{3}$ were added independently. None of these treatments led to proliferation inhibition (data not shown), except DMSO at $2.5 \%$ (v/v). Although LISP-1 doubling time, $20 \pm 1 \mathrm{~h}$ under standard culture conditions, was weakly affected by $1.25 \%$ DMSO treatment (doubling time $=24 \pm 3 \mathrm{~h}$ ), it nearly quadruplicated when DMSO concentration was raised up to $2.5 \%(82 \pm 3 \mathrm{~h}$; $\mathrm{P}<0.05$, ANOVA). This optimal effects of $2.5 \%$ DMSO over a period of 10 days (from here on considered as standard DMSO treatment) occurred without affecting cell viability, which remained constant at $98 \%$ with cells adherent to plastic, without detachment, until the end of the experiment.

Cell cycle phase distribution, determined at various intervals after $2.5 \%$ DMSO treatment, provided clear evidence of an accumulation of LISP-1 cells at the G0/G1 phase 
of the cell cycle, which was associated with increased doubling time (Figure 1A). By the 4th day of exposure, the G0/G1 phase fraction had significantly changed (control: 55.0 $\pm 2.4 \%$ vs DMSO: $70.7 \pm 2.5 \%$; Figure $1 \mathrm{C}$ ). This difference was maintained until the conclusion of the experiment at 10 days, as shown in Figure 1C. In parallel, we have observed a steep decrease (7-fold) in the expression of c-myc mRNA (Figure 1B).

\section{Integrin expression}

Assessment of $\beta 1$ integrin receptors using flow cytometry and anti-integrin mAbs showed that LISP-1 cells display a high percentage of $\alpha 3$ and $\beta 1$ integrin subunit-positive cells, whereas $\alpha 6$ expression was relatively low and $\alpha 2$ and $\alpha 5$ were only moderately expressed. In contrast, $\alpha 1, \alpha 4, \alpha v$ and ß4 were not detected at all. DMSO decreased the percent of $\alpha 5$ - and $\alpha 6$-positive cells without affecting $\alpha 2$ or $\beta 1$ subunit expression. Differences in the expression of $\alpha 3$ in LISP-1 cells were only observed at mean fluorescence intensity level (Table 1).

Although time course analyses indicated that the expression of $\alpha 3, \alpha 5$ and $\alpha 6$ was reduced after DMSO exposure, only the decrease of $\alpha 5$ and $\alpha 6$ integrin expression was simultaneous to G0/G1 cell accumulation. In parallel, the expression of $\beta 1$ integrin subunits displayed by control cells, determined at the same times, did not change during the entire experiment. The results obtained for $\alpha 3, \alpha 5$ and $\alpha 6$ integrin expression are presented in Figure 2.

To characterize whether these changes in integrin expression were related to G0/G1 arrest upon DMSO treatment, we compared $\alpha 3$ and $\alpha 6$ integrin expression displayed by cells in G0/G1 and $\mathrm{S}+\mathrm{G} 2 / \mathrm{M}$ phase fractions after 10 days of DMSO treatment or under standard cell culture conditions. We observed that the fluorescence intensity of $\alpha 6$ integrin was reduced in the G0/G1 phase fraction (control: $51.6 \pm 3.7$ vs DMSO: $33.73 \pm 3.4$;
$\mathrm{P}<0.05)$, an event that did not occur in the $\mathrm{S}$ + G2/M phase (control: $62.1 \pm 2.8$ vs DMSO: $56.4 \pm 7.5$; Figure 3 ). A similar decrease in $\alpha 3$ integrin was observed through $\mathrm{G} 0 / \mathrm{G} 1$ (control: $283.9 \pm 19.8$ vs DMSO: $201.1 \pm$ 7.4) to $\mathrm{S}+\mathrm{G} 2 / \mathrm{M}$ (control: $280.9 \pm 26.4 \mathrm{vs}$ DMSO: $197.2 \pm 21.4)$.

Table 1. Dimethyl sulfoxide (DMSO) modulation of $\beta 1$ integrin subunit expression in LISP-1 cells.

\begin{tabular}{lccccc}
\hline \multirow{2}{*}{ mAbs } & \multicolumn{2}{c}{ Control } & & \multicolumn{2}{c}{ DMSO } \\
\cline { 2 - 3 } \cline { 5 - 6 } & \multicolumn{2}{c}{$\%$} & MFI & & \multicolumn{1}{c}{ MFI } \\
\hline$\alpha 2$ & $63.8 \pm 11.3$ & $198.3 \pm 26.4$ & & $56.1 \pm 25.1$ & $176.2 \pm 0.4$ \\
$\alpha 3$ & $93.3 \pm 7.0$ & $348.3 \pm 20.4$ & & $81.1 \pm 19.2$ & $208.7 \pm 30.1^{*}$ \\
$\alpha 5$ & $50.4 \pm 12.0$ & $170.9 \pm 14.1$ & & $24.2 \pm 19.0^{*}$ & $100.0 \pm 28.7^{*}$ \\
$\alpha 6$ & $34.1 \pm 4.9$ & $126.5 \pm 28.4$ & & $14.3 \pm 10.8^{*}$ & $111.7 \pm 20.0$ \\
B1 & $99.3 \pm 0.5$ & $276.3 \pm 40.5$ & & $92.2 \pm 5.9$ & $226.2 \pm 52.9$
\end{tabular}

Cells were incubated with specific monoclonal antibodies (mAbs) and analyzed by flow cytometry as described in Material and Methods. Data are reported as percent of integrin-positive cells and mean fluorescence intensity (MFI). Data are the mean $\pm \mathrm{SD}$ for 5 experiments.

${ }^{*} \mathrm{P}<0.05$ compared to control (ANOVA).
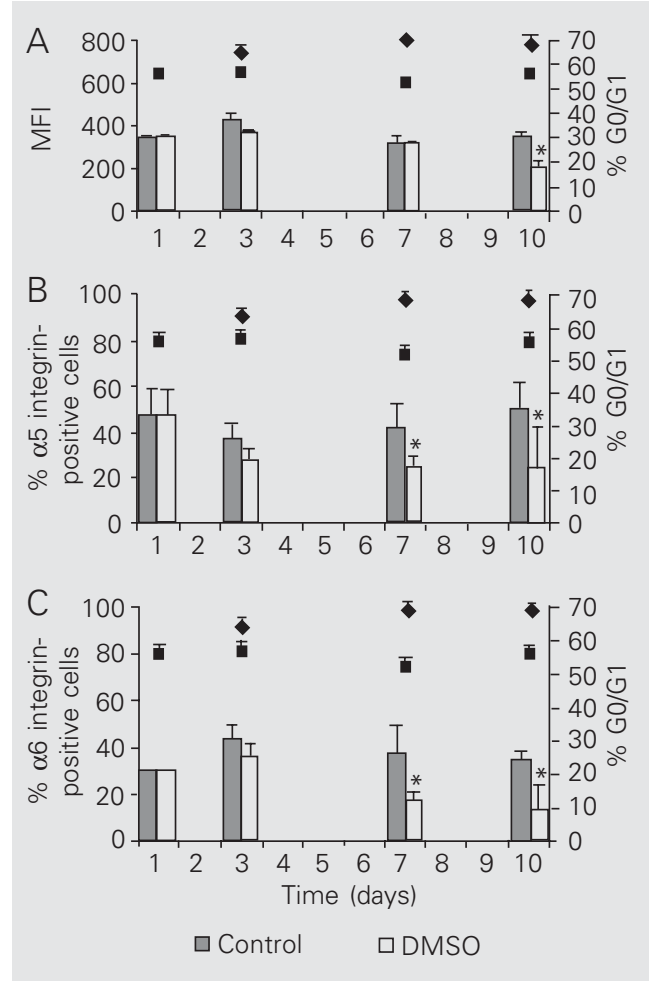

Figure 2. Time course of integrin expression and percent cells in G0/G1 during dimethyl sulfoxide (DMSO) treatment of LISP-1. Control cells (filled bars) and DMSO-treated cells (open bars) indicate the variation of mean fluorescence intensity (MFI) (A) and the percent of positive cells for $\alpha 5$ (B) and $\alpha 6$ (C) integrin (left y-axis). The percent of G0/G1 fraction (right $y$ axis) is represented for control cells and DMSO-treated cells. Data are the mean \pm SD obtained for 5 independent experiments. ${ }^{*} P<0.05$ compared to control (ANOVA). 


\section{Cell adhesion and migration assays}

We next compared the rate of adhesion by control and DMSO-treated cells to elements of the ECM, namely, laminin-1, fibronectin and collagen type I or IV. LISP-1 cells adhered efficiently to laminin-1 $(73.4 \pm 6.0 \%)$
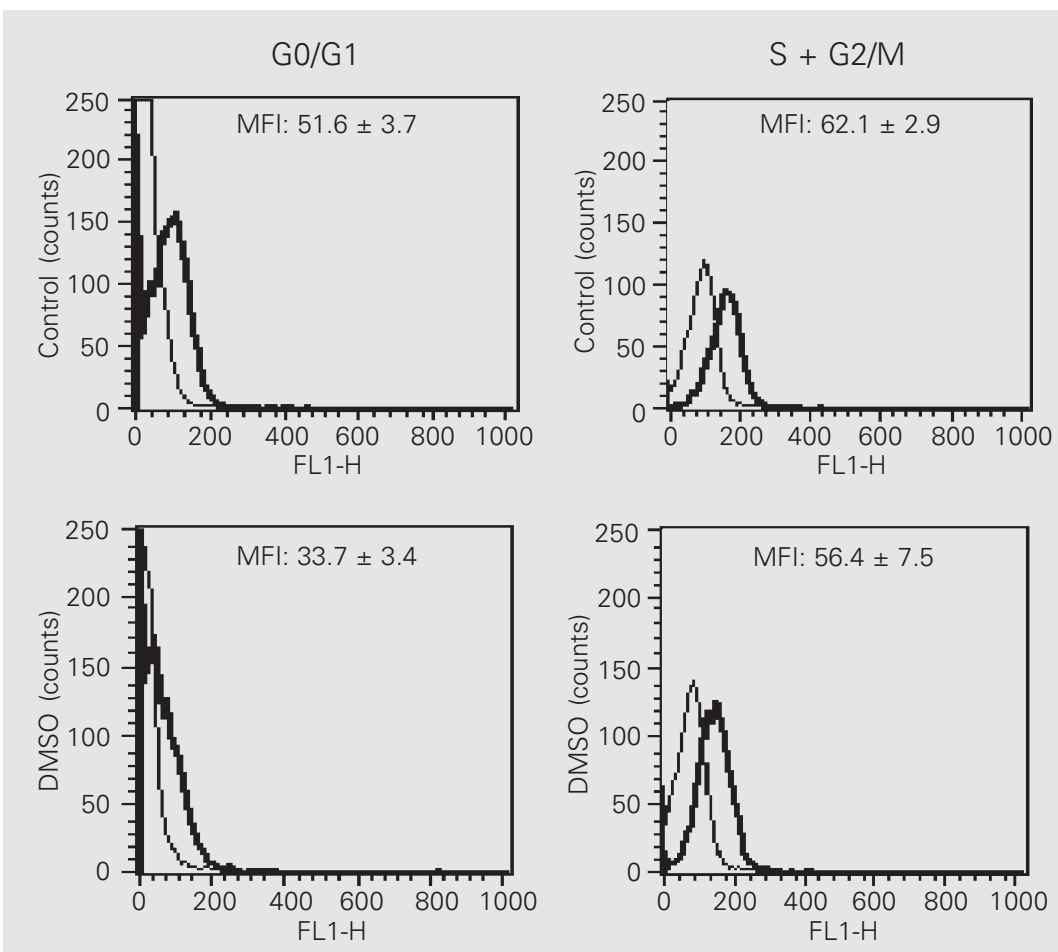

Figure 3. Dimethyl sulfoxide (DMSO) decreased expression of $\alpha 6$ integrin in LISP-1 cells in G0/G1 but not in $\mathrm{S}+\mathrm{G} 2 / \mathrm{M}$. Expression of $\alpha 6$ integrin as a function of cell cycle phase was determined as described in Methods. The fine line and thick line correspond to the background and integrin expression, respectively. Fluorescence data are the mean $\pm S D$ for 4 independent experiments. MFI = mean fluorescence intensity

Figure 4. Dimethyl sulfoxide (DMSO) treatment does not affect laminin-1 or fibronectin adhesion, with only collagen type IV cell adhesion being weakly increased. [35S]-Methionine-labeled cells were added to surfaces precoated with $20 \mu \mathrm{g} / \mathrm{well}$ of laminin-1 or $10 \mu \mathrm{g} / \mathrm{well}$ of other ECM components for $1 \mathrm{~h}$ at $37^{\circ} \mathrm{C}$, in a $5 \% \mathrm{CO}_{2}$ atmos

phere. ECM-attached cells were dissolved with $0.5 \mathrm{~N} \mathrm{NaOH} / 1 \%$ SDS, and radioactivity was counted in a Beckman $B$ counter. Each experiment was performed in triplicate wells. Data are the mean $\pm \mathrm{SD}$ for 5 independent experiments. $\mathrm{Cl}=$ collagen type $\mathrm{I} ; \mathrm{CIV}=$ collagen type IV; Fn = fibronectin; $L n-1=$ laminin-1. and moderately to fibronectin $(40.0 \pm 2.0 \%)$, but did not attach to collagens at all. We did not see any gross change in LISP-1 adhesion after DMSO treatment. Adhesion to collagen type IV continued to be below $10 \%$ (Figure 4).

Adhesion inhibition in the presence of mAbs confirmed that adhesion of LISP-1 cells to laminin-1 was mainly mediated by $\alpha 2, \alpha 3$ and $\alpha 6$ integrins. After DMSO exposure, the relative contribution of $\alpha 2$ and $\alpha 6$ decreased, turning $\alpha 3$ into the major laminin-1 receptor (Table 2). Fibronectin adhesion before DMSO exposure was not mediated by $\alpha 3$ or by $\alpha 5$ but, after treatment, $\alpha 5$ integrin accounted for $89.9 \pm 2.0 \%$ of fibronectin total adhesion.

Finally we observed how DMSO treatment affected migratory activity of LISP-1 cells by using a Neuro Probe chamber assay. Very few cells ( $6 \pm 2$ cells) migrated spontaneously towards laminin- 1 , whereas $64 \pm 6$ cells did it after 10 days of exposure to DMSO. This migration towards laminin-1 was inhibited $100 \%$ in the presence of the $\alpha 6$-recognizing mAb. On the other hand, we did not observe any LISP-1 migratory activity towards fibronectin or collagens either before or after DMSO treatment.

\section{Discussion}

We have shown here that, although resistant to several commonly used antiproliferative agents such as 1,25-dihydroxyvitamin $\mathrm{D}_{3}$ and retinoic acid, LISP-1 cell growth was inhibited by DMSO, a polar solvent which acts as a powerful scavenger of oxygen radicals (24). DMSO treatment lengthened LISP1 doubling time as described previously for other poorly differentiated colonic cells $(15,16)$, increasing the $\mathrm{G} 0 / \mathrm{G} 1$ phase fraction as in other two models, i.e., human leukemia and Chinese hamster ovary $(\mathrm{CHO})$ cells $(25,26)$. The corresponding down-regulation of the c-myc mRNA levels already reported in other cell models $(27,28)$ confirmed that the cell cycle of LISP-1 was arrested in 
response to DMSO.

Changes in S-phase compartments have been previously reported to be associated with changes in different integrins, namely CD11b, $\alpha 4$ and $\alpha 2$ in hematopoietic and fibroblast cell lines (6-8). How these changes might affect adhesion and migration had never been addressed before in colorectal cancer cells.

In the present report, time course analysis indicated that DMSO down-regulated $\alpha 3$, $\alpha 5$ and $\alpha 6$ integrin subunit expression, but only the expression of $\alpha 5$ and $\alpha 6$ integrins was reduced concomitantly with G0/G1 cell cycle arrest. It is also interesting to note that the changes in expression occurred via an alteration of $\alpha$ subunits while the $\beta 1$ expression remained constant.

We first asked if the decreased $\alpha 3, \alpha 5$ and $\alpha 6$ integrin expression could be attributed to changes in cell density as suggested in previous reports (29). This hypothesis was ruled out since no association between cell density and variation of integrin expression was seen in control cells.

We may speculate that transcription factors such as the above mentioned c-myc, or even AP-1, might play a role by regulating proliferation and consequently integrin expression. A binding site for AP-1 in the promoter region of both $\alpha 5$ and $\alpha 6$ integrin as well as for c-myc in the corresponding $\alpha 6$ integrin promoter region has been previously identified $(30,31)$. Although the data presented here do not demonstrate a corresponding reduction in the expression of $\alpha 6$ integrin at the mRNA level, it is possible that the decreased c-myc mRNA levels might underscore the effects of DMSO in reducing $\alpha 6$ integrin protein expression. Adhesion molecules have been shown to be primary DMSO targets in other cell culture models. Increased $\alpha 631$ integrin expression in the LA7 murine mammary cell line (32) and an increase in both $\alpha 5 \beta 1$ and cadherin expression in CHO cells (26) were reported following DMSO exposure.
B4 integrin, which was the only integrin previously described as affecting proliferation in colorectal cancer cells (33), was discarded since, in our experiments, it was absent in the LISP-1 cell line.

The reduced proliferation of LISP-1 cells grown in the presence of DMSO might also indicate a more "benign" phenotype, in agreement with colorectal cell studies showing that the normal mucosa or well-differentiated tumors has lower expression of $\alpha 5$ compared to less differentiated or metastatic lesions $(9,34)$.

With all of these changes in integrin expression, we did not expect LISP-1 to retain its adhesion characteristics as far as laminin-1 and fibronectin were concerned after being exposed to DMSO. Maintenance of adhesion perhaps reflects changes in integrin affinity depending on intracellular signaling (35). Effects such as those described for DMSO modulating protein kinase $\mathrm{C}$ activity (36) may result in the modulation of integrin phosphorylation and cytoskeletal remodeling as reported for in vitro treatment with phorbol myristate acetate (37).

The $10 \%$ adhesion increase in collagen type IV substrate that we have observed might be a consequence of changes involving integrin affinity for other ECM. Taking into account that $\alpha 2$ integrin is a laminin/ collagen bifunctional receptor, and that $\alpha 2$

Table 2. Dimethyl sulfoxide (DMSO, 2.5\%, v/v) inhibits laminin-1 adhesion to LISP-1 cells.

\begin{tabular}{lcc}
\hline mAbs & Control (\%) & DMSO (\%) \\
\hline$\alpha 2$ & $45.3 \pm 1.4$ & $15.0 \pm 0.8$ \\
$\alpha 3$ & $37.2 \pm 2.6$ & $69.1 \pm 9.0$ \\
$\alpha 6$ & $22.6 \pm 3.0$ & $*$ \\
$\beta 1$ & $65.8 \pm 7.0$ & $69.3 \pm 2.6$ \\
$\alpha 2+\alpha 3+\alpha 6$ & $65.8 \pm 2.2$ & $83.1 \pm 5.5$
\end{tabular}

The inhibition of cell adhesion to laminin-1 was determined in the presence of blocking monoclonal antibodies (mAbs) against integrin subunits and is reported as mean percent \pm SD for 5 independent experiments. ${ }^{*} \mathrm{mAbs}$ did not inhibit cell adhesion to laminin-1. 
expression remained constant, we might suggest that a higher collagen type IV adhesion was favored by a diminished participation of this receptor in laminin-1 adhesion (Table 2). Unfortunately, we were unable to test this hypothesis using blocking antibodies, since the magnitude of changes occurring in LISP-1 adhesion to collagen type IV (10\%) was too small to be tested.

Although not addressed in colorectal cancer, changes in affinity may have an impact on other integrin functions, since it is not clear if adhesion and migration on a given substratum depend on the same parameters as those related to integrin-ligand interactions and integrin expression (38). In the present study, DMSO treatment favored migration towards laminin-1 without altering adhesion. Our antibody inhibition experiments showed that $\alpha 6$ antibody fully inhib- ited migration towards laminin-1, suggesting that this receptor remained active in cell migration, although being replaced by $\alpha 3$ integrin in adhesion.

In summary, we found: i) a close temporal relationship between growth arrest induced by DMSO and reduction of c-myc mRNA and of $\alpha 5$ and $\alpha 6$ integrin expression, ii) no correspondence between changes in integrin expression and rates of cell adhesion to laminin-1 and fibronectin, and iii) migration towards laminin-1 favored by DMSO, possibly due to an almost complete loss of $\alpha 6$ integrin participation in laminin-1 adhesion. Since our results support the idea that not only expression, but also affinity is important in determining adhesion/migration, future studies addressing integrins as therapeutic targets should take these factors into consideration.

\section{References}

1. Bartolazzi A, Cerboni C, Nicotra MR, Mottolese M, Bigotti A \& Natali PG (1994). Transformation and tumor progression are frequently associated with expression of $\alpha 3 / \beta 1$ heterodimer in solid tumors. International Journal of Cancer, 58: 488-491.

2. Beaulieu JF (1999). Integrins and human intestinal cell functions. Frontiers in Bioscience, 4: 310-321.

3. Ohtaka K, Watanabe S, Iwazaki R, Hirose M \& Sato N (1996). Role of extracellular matrix on colonic cancer cell migration and proliferation. Biochemical and Biophysical Research Communications, 220: 346-352.

4. Ebert EC (1996). Mechanisms of colon cancer binding to substratum and cells. Digestive Diseases and Sciences, 41: 1551-1556.

5. Haier J, Nasralla M \& Nicolson GL (1999). Different adhesion properties of highly and poorly metastatic HT-29 colon carcinoma cells with extracellular matrix components: role of integrin expression and cytoskeletal components. British Journal of Cancer, 80: 18671874.

6. Lee W \& McCulloch CA (1997). Deregulation of collagen phagocytosis in aging human fibroblasts: effects of integrin expression and cell cycle. Experimental Cell Research, 237: 383-393.

7. Yamaguchi M, Ikebuchi K, Hirayama F, Sato N, Mogi Y, Ohkawara J, Yoshikawa Y, Sawada K, Koike T \& Sekiguchi S (1998). Different adhesive characteristics and VLA-4 expression of CD34(+) progenitors in G0/G1 versus $\mathrm{S}+\mathrm{G} 2 / \mathrm{M}$ phases of the cell cycle. Blood, 92: 842-848.

8. Folgueira MAAK, Federico MHH, Katayama MLH, Silva MRP \& Brentani MM (1999). Expression of vitamin D receptor (VDR) in HL60 cells is differentially regulated during the process of differentiation induced by phorbol ester, retinoic acid and interferon-gamma. Journal of Steroid Biochemistry and Molecular Biology, 66: 193-201.
9. Streit M, Schmidt R, Hilgenfeld RU, Thiel E \& Kreuser ED (1998). Adhesion receptors in malignant transformation and dissemination of gastrointestinal tumors. Journal of Molecular Medicine, 74: 253268.

10. Solimene AC, Carneiro CR, Melati I \& Lopes JD (2001). Functional differences between two morphologically distinct cell subpopulations within a human colorectal carcinoma cell line. Brazilian Journal of Medical and Biological Research, 34: 653-661.

11. Udagawa T, Hoppwood VL, Pathak S \& Mclntyre BW (1995). Integrin-mediated entry into $S$ phase of human gastric adenocarcinoma cells. Clinical and Experimental Metastasis, 13: 427-438.

12. Blottiere HM, Zennadi R, Gregoire M, Aillet G, Denis MG, Meflah K \& Le Pendu J (1993). Analysis of the relationship between stage of differentiation and NK/LAK susceptibility of colon carcinoma cells. International Journal of Cancer, 53: 409-417.

13. Waliszewski P, Waliszewska MK, Gupta M, Milsom JW \& Hurst RE (1997). Expression of retinoid-responsive genes occurs in colorectal carcinoma-derived cells irrespective of the presence of resistance to all-trans retinoic acid. Journal of Surgical Oncology, 66: 156-167.

14. Kane KF, Langman MJ \& Williams GR (1996). Antiproliferative responses to two human colon cancer cell lines to vitamin D3 are differently modified by 9-cis-retinoic acid. Cancer Research, 56: 623-632.

15. Tsao D, Morita A, Bella JR, Luu P, Rennard JM \& Kim YS (1982) Differential effects of sodium butyrate, dimethyl sulphoxide, and retinoic acid on membrane-associated antigen, enzymes, and glycoproteins of human rectal adenocarcinoma cells. Cancer Research, 42: 1052-1058.

16. Omary MB, Grandpre L, McCaffrey M \& Kagnoff MF (1992). Biochemical and morphological differentiation of the human colonic 
epithelial cell line SW620 in the presence of dimethylsulfoxide. Journal of Cellular Biochemistry, 48: 316-323.

17. Prado I, Laudanna AA \& Carneiro CRW (1995). Susceptibility of colorectal-carcinoma cells to natural-killer-mediated lysis: relationship to CEA expression and degree of differentiation. International Journal of Cancer, 61: 854-860.

18. Vindelov LL \& Christensen IJ (1990). A review of techniques and results obtained in one laboratory by an integrated system of methods designed for routine clinical flow cytometric DNA analysis. Cytometry, 11: 753-770.

19. Watt R, Stanton LW, Marcu KB, Gallo RC, Croce CM \& Rovera G (1983). Nucleotide sequence of cloned cDNA of human c-myc oncogene. Nature, 3: 725-728.

20. Fort P, Marty L, Piechaczyk M, el Sabrouty S, Dani C, Jeanteur P \& Blanchard JM (1985). Various rat adult tissues express only one major mRNA species from the glyceraldehyde-3-phosphate-dehydrogenase multigenic family. Nucleic Acids Research, 13: 14311442.

21. Braylan R, Berson NA, Nourse V \& Kruth HS (1982). Correlated analysis of cellular DNA: Membrane antigens and light scatter of human lymphoid cells. Cytometry, 2: 337-343.

22. Timpl R, Rohde H, Robey PG, Rennard SI, Foidart J \& Martin GR (1979). Laminin - A glycoprotein from basement membranes. Journal of Biological Chemistry, 254: 9933-9937.

23. Strom SC \& Michalopoulos G (1982). Collagen as substrate for cell growth and differentiation. Methods in Enzymology, 82: 544-555.

24. Zhi-wu Y \& Quinn PJ (1994). Dimethyl sulphoxide: A review of its applications in cell biology. Bioscience Reports, 14: 259-281.

25. Teraoka H, Mikoshiba M, Takase K, Yamamoto K \& Tsukada K (1996). Reversible G1 arrest induced by dimethyl sulfoxide in human lymphoid cell lines: Dimethyl sulfoxide inhibits IL-6 induced differentiation of SKW6-CL4 into IGM secreting plasma cells. Experimental Cell Research, 222: 218-224.

26. Fiore M \& Degrassi F (1999). Dimethyl sulfoxide restores contact inhibition-induced growth arrest and inhibits cell density-dependent apoptosis in hamster cells. Experimental Cell Research, 251: 102110.

27. Darling D, Tavassoli M, Linskens $M H$ \& Farzaneh $F$ (1989). DMSO induced modulation of c-myc steady-state RNA levels in a variety of different cell lines. Oncogene, 4: 175-179.
28. Srinivas S, Sironmani TA \& Shanmugam G (1991). Dimethyl sulfoxide inhibits the expression of early growth-response genes and arrests fibroblasts at quiescence. Experimental Cell Research, 196: 279-286.

29. Stanley AJ, Banks RE, Southgate J \& Selby PJ (1995). Effect of cell density on the expression of adhesion molecules and modulation by cytokines. Cytometry, 21: 338-343

30. Nishida K, Kitazawa R, Mizuno K, Maeda S \& Kitazawa S (1997). Identification of regulatory elements of human alpha 6 integrin subunit gene. Biochemical and Biophysical Research Communications, 241: 258-263.

31. Corbi AL, Jensen UB \& Watt FM (2000). The alpha2 and alpha5 integrin genes: identification of transcription factors that regulate promoter activity in epidermal keratinocytes. FEBS Letters, 474: 201-207.

32. Zucchi I, Montagna C, Susani L, Montesano R, Affer M, Zanotti S, Redolfi E, Vezzoni P \& Dulbecco R (1999). Genetic dissection of dome formation in a mammary cell line: Identification of two genes with opposing action. Proceedings of the National Academy of Sciences, USA, 96: 13766-13770.

33. Clarke AS, Lotz MM, Chao C \& Mercurio AM (1995). Activation of the p21 pathway of growth arrest and apoptosis by the beta 4 integrin cytoplasmic domain. Journal of Biological Chemistry, 270: 22673-22676.

34. Gong J, Wang D, Sun L, Zborowska E, Willson JK \& Brattain MG (1997). Role of alpha 5 beta 1 integrin in determining malignant properties of colon carcinoma cells. Cell Growth Differentiation, 8: 83-90.

35. Hughes PE \& Pfaff M (1998). Integrin affinity modulation. Trends in Cell Biology, 8: 359-364.

36. Cataldi A, Di Pietro R, Centurione L, Grilli A, Centurione G \& Miscia S (2000). Phosphatidylinositol-3-kinase activation and atypical protein kinase C zeta phosphorylation characterize the DMSO signalling in erythroleukemia cells. Cellular Signalling, 12: 667-672.

37. Rigot V, Lehmann M, André F, Daemi N \& Marvaldi J (1998). Integrin ligation and PKC activation are required for migration of colon carcinoma cells. Journal of Cell Science, 111: 3119-3127.

38. Palecek SP, Loftus JC, Ginsberg MH, Lauffenburger DA \& Howitz AF (1997). Integrin-ligand binding proporties govern cell migration speed through cell-substratum. Nature, 385: 537-540. 